\title{
Beauty in Bastardy? Breytenbach on Afrikaans and the Afrikaners
}

\section{Brian Kennelly, Webster University}

The Afrikaner is bursting out of his definitions of himself as well as those of others.

—Willem de Klerk, former editor of Rapport

Throughout the twentieth century activists in South Africa for the Afrikaans language struggled with, yet never resolved, the language/people, Afrikaans/Afrikaner issue, as Hermann Giliomee points out in his recent ‘biography' of the Afrikaners (2003, 389). Was the Afrikaner community a racial or linguistic one? Was the push to promote Afrikaans subordinate to the entrenchment of a white supremacist government and ruling party? Was there a hegemonic or counter-hegemonic relationship between language and ethnicity? If the social identity of the Afrikaner was to be shaped by the acceptance of Afrikaans as a public language on equal footing with English, the creed that the language constitutes the entire people ('die taal is gans die volk') had to be race-blind.

In the ever-changing South African society of the twenty-first century, it is no surprise that old labels and new identities are still 'simmering' (Swarns 1999). The concept of Afrikaner 'identity' is situated in a field of contesting meanings (Wasserman 2001, 37). New patterns and relationships are yet to be established (Brink 1998, 119). South Africa constitutes a 'virtual battleground' for the various actors who are trying to define Afrikanerskap (Vestergaard 2001, 28). The democratic political dispensation has given rise to the 'decolonization of colonial contact zones' (Steinwand 2002, para. 6) and 'New South Africa-speak' (Wicomb 2002, 146). All are testing the depth of Afrikaners' identification with cultural issues they once held dear (Van Zyl Slabbert 2000, 157). 
The Conservative Party, for example, joined forces in September 2003 with the Freedom Front and the Afrikaner Unity Movement to become the Freedom Front Plus, a party 'irrevocably committed to the protection and advancement of Afrikaner interests' (Vryheidsfront Plus). Ferdi Hartzenberg, who had led the Conservatives, was asked to define the term 'Afrikaner.' He brushed off and sidestepped the question, deeming it both irrelevant and passé. He claimed that the issue that had long plagued language activists had been settled: 'All the people know what an Afrikaner is. The African National Congress knows what an Afrikaner is. The time for formulating such definitions has passed’ (de Beer 2003, para. 1).

By focusing on the present at the same time as looking forward to a more enlightened future for youthfully postcolonial South Africa (Wicomb 1996, 7), Hartzenberg and others like him cannot, however, overlook the 43 years constituting its deeply troubling recent apartheid past. In the latter half of the twentieth century, white supremacists were the architects and overlords of its system of exclusive and legalized racial intolerance. Indeed, they had been the group defining Afrikaners. They had distinguished, but also tainted themselves by participating in what South Africa’s third Nobel Prize winner, John Maxwell Coetzee, terms 'an audacious and well-planned crime against Africa' (1992, 342). ${ }^{1}$

Frederik Van Zyl Slabbert, the former leader of the Progressive Federal Party, seems more reasonable, and certainly more reflective, than Hartzenberg. He grapples in his writings with the perennially thorny problem of how to define and categorize Afrikaners. In his effort to tackle tough questions of identity and politics as they are rehearsed and rerehearsed both locally and nationally in the 'Rainbow Nation,' Van Zyl Slabbert privileges compromise and exchange, idea-sharing over stonewalling. ' 'To be called an

\footnotetext{
${ }^{1}$ A more 'enlightened' future is, of course, no guarantee of its stability. Interviewed at the Voortrekker monument at the same time as Reconciliation Day celebrations were taking place not far away, Don Pretorius for example painted a bleak future for certain South Africans: 'It's actually very unsure for us here. We don't know if the same thing will happen here as happened in Zimbabwe' (Dixon 2004).

${ }^{2}$ In his article on identity and nation-building in post-apartheid South Africa, Gary Baines notes that Archbishop Desmond Tutu is usually credited with coining this term (2003, para. 2).
} 
Afrikaner,' he therefore cautions, 'is the beginning of a discussion, never the final word' $(2000,24)$.

Such discussion is made more salient by Giliomee's more-than-seven-hundred-page study The Afrikaners: Biography of a People, which reveals that the very concept of 'Afrikaner' has always been contested in spite of the predominant sense of ethnic unity (Alexander 2003). The writings of the 'sometime' (Schalkwyk 1994, 24) Afrikaner artist, playwright, essayist, 'terrorist,' and poète maudit Breyten Breytenbach on the Afrikaans language and Afrikaner people further nuance, extend, and even complicate the discussion. In the wake of the acrimonious debate provoked by this self-described 'nadaist,' 'nomad,' 'Afrikaner Azanian pariah’ $(1996,8,15)$, 'one-eyed wind jackal,' and 'philosidiot' $(2000,11)$ during the apartheid years over the bastard nature of Afrikaner identity (Schalkwyk 1994, 27), what is Breytenbach's 'controversial conception' (1986, 94) of what it might mean, or have meant, to be an Afrikaner and to speak Afrikaans? And in the cacophony over Afrikaner cultural identity (Vestergaard 2001, 22) as South Africa moves beyond the dark legacy, the 'lengthy dismemberment and agony of cultures and ethics' (Breytenbach 1988, 115) of its past and rebuilds itself for a more inclusive future, how can the redefinitive role Breytenbach envisions for Afrikaners and the language they speak be seen both recuperative and reconciliative?

\section{From Bastertaal to the Law of the Bastard}

The sense of being Afrikaner had only crystallized by the end of the eighteenth century for the colonists in Southern Africa who had previously referred to themselves as burghers, Christians, or Dutchmen (Giliomee 2003, 50-1). By the end of the twentieth century, however, the term 'Afrikaner' had become increasingly limited and ideologized. As white Afrikaans speakers, the Afrikaners were that part of the Afrikaans language community forming the ruling class (Wasserman 2001, 37). Described by the philosopher Martin Walser as a 'people on the wrong side of history' (Brink 1998, 72), they saw themselves as a volk. They had a teleological belief in their historically defined role (Reckwitz 1993, 21). They were, Breytenbach sarcastically states, 'a people with a mission, put there by God with a purpose' $(1986,197)$; they were to fulfill their destiny 
as Christians, as a civilization (Moodie 1975, 11). They were the only whites in South Africa who saw themselves as having become 'truly indigenous' and who were prepared to fight to the end for white supremacy (Giliomee 2003, xvi). The term, Afrikaner, Coetzee observes (1992, 342), had been first hijacked by a primarily anti-British but also anti-black political movement calling itself Afrikaner Nationalism. 'Afrikaner' thereby became an exclusive classification. Those speaking Afrikaans as their first language however were not accepted as Afrikaners if they failed to meet further racial, cultural, and political criteria.

With the sharply drawn group identities enforced by this eugenically based system (Van Zyl Slabbert 2000, 79), apartheid was intolerant of variation. Just as blacks could be imprisoned for not carrying a 'pass,' white Afrikaans speakers who disagreed with or acted against the racial, indeed racist, policy of the government were seen as opposing not only their people but the will of God. Heretical, these 'bad Afrikaners' could also be judged guilty of treason.

By 1983 Breytenbach no longer considered himself an Afrikaner. He had served seven of the nine years to which he had been sentenced for conspiring against the state- - two of them in solitary confinement. For him, the 'concept' (1983a, 6) had taken on a political and cultural content with which he could no longer identify $(1986,102){ }^{3}$ To be an Afrikaner, in his eyes, was to have been successfully 'programmed' by Die Burger, state television, and the syllabi of such cultural bastions as the universities of Stellenbosch and Pretoria. It was to be a life-long hostage of the Broederbond, prey to the journalists, teachers, commando officers, and pastors who, he warned, were really 'opinion-spinning spiders' (1986, 30). To be an Afrikaner, he furthermore opined, was to be 'a blight and a provocation to humanity,' 'a living insult to whatever better instincts [...] human beings may possess and struggle to maintain’ (1983b, 280, 354). As a result, Breytenbach emphasized at that time, nothing could ever bridge the gap between himself and the

\footnotetext{
${ }^{3}$ Breytenbach was tried and convicted for terrorism in 1975. He had returned incognito to South Africa from France (where he had lived since 1961 in exile with his Vietnamese, and thus legally 'non-white,' wife) and attempted to garner support for the resistance group 'Okhela,' for which he had written the political platform. He returned to Paris in 1982.
} 
authorities of the Afrikaner tribe. These 'overdogs,' 'bastards in power' (Linfield 2000-1, 270) were 'tragically defending a superannuated vision of Western civilization' (Breytenbach 1986, 197). He has since come to terms with his Afrikaner identity, however. He realizes that his exiled 'years of dawdling by the fleshpots of Paris' ultimately did not make him any less of an Afrikaner (1996, 32). He wrote in 1993, for example, of ‘scratching’ for his Afrikaner roots again (1993, 80).

While not exclusive to them, the first language of Afrikaans is today the 'primary' or probably the 'simplest' means by which to identify members of the Afrikaner tribe from whom Breytenbach so distanced himself more than two decades ago. As such, speaking Afrikaans could be considered their 'most common characteristic' (Louw-Potgieter 1988, 51). In essence, Afrikaans was a dialect of Dutch that over time underwent a limited measure of creolization (Giliomee 2003, 53). It was shaped in large part by those unable to speak proper Dutch (Brink 1998, 76). It had, moreover, been scorned by the English newspaper The Cape Argus in the nineteenth century as 'a "miserable, bastard jargon” [...] not worthy of the name of "language” at all' (Giliomee 2003, 203). Likewise, readers of the Cape Times considered it 'mongrel,' 'kitchen,' 'hotch-potch,' 'degenerate,' and 'decaying'; it was only fit for 'peasants and up-country kraals' (Giliomee 2003, 367). In fact, as late as the early twentieth century, shortly before being codified and elevated by the Afrikaans 'culture brokers' (Willemse 1991, 261) as 'the youngest prince of the family of the Germanic languages’ (Breytenbach 1983a, 6), Afrikaans still carried the stigma of a bastard tongue (bastertaal). It was considered the language of the uneducated (Giliomee 2003, 224).

Breytenbach sought to dissociate himself from the 'official' Afrikaans imposed on South Africans during the apartheid years. He long viewed it as the 'excuse and reinforcement for the utter perversion of racial baasskap' $(2000,10)$, the 'language for tombstones' (1991, 182), and portrayed it in his poetry, for instance, as 'a grey reservist of a hundred years old and more,' with a 'grammar of violence' and 'syntax of destruction' (1983b, 356-7). But he finds ‘astonishing beauty’ $(1986,102)$ in its bastardy today. He notices 
that Afrikaans, now one of eleven official languages in South Africa but ironically the only language on the continent to call itself 'African' $(1988,115)$, still clearly bears the traces of its 'beautiful, bastard' (2000-1, 271) origins: 'that marriage between the sea, the story of sailors and slaves from many regions, and the inland vernacular of settler peasants and indigenous peoples' $(1988,15)$. In his 1999 memoir, Breytenbach ties the bastardy for which Afrikaans was long stigmatized to the losses and gains of past and present:

My language speaks of the loss of purity, I mix Europe and the East and Africa in my veins, my cousin is a Malagasy; my tongue speaks about moving away from the known, about overflowing into the unknown, about making; of dispossessing, plundering, enslavement, mixing; of the transmission under guise of a 'new' language of that which refuses to be forgotten, of discovery but of agreement also (because comparison is as well a compromise), of the land and of light, of the art of surviving. I'm a Dutch bastard, my father is French and my mother is Khoi. Each grave in this purple earth is a place of exile [....] our specific language, Afrikaans, is the visible history and the ongoing process not only of bastardisation, but also of metamorphosis (175-6).

Like the Company Gardens, the strategic halfway house for Dutch East India Company sailors, the language spoken there bridged and ultimately incorporated continents and cultures. Similarly, as Afrikaans speakers trekked from the southern tip of Africa into the harsh hinterland, their language survived as they did-by adapting. No less 'new' than 'specific' to the people its speakers dispossessed, plundered, and enslaved, Breytenbach paints yet praises his native tongue as illicit and impure.

The poet Breytenbach suggests that Afrikaans should be seen as 'a new avatar of that supple lingo of seafarers, slaves and nomads - of people who constantly have to invent themselves' (1993, 211). It should, furthermore, be recognized as dynamic and under perpetual reinvention. It is far richer and robust than the funereal, government-imposed language from which he once distanced himself. ${ }^{4}$ Novelist André Brink, for example, observes that at the same time Afrikaans was turned into the language of apartheid by 'misguided ideas of ethnic and linguistic purity,' an 'alternative' and resilient Afrikaans

\footnotetext{
${ }^{4}$ In his study of how Afrikaans was portrayed in the 'overtly Afrikaner nationalist-inclined' South African textbooks during the years of apartheid, Hein Willemse argues that the history of Afrikaans was, for many years, 'essentially an invented myth.' During that time popular, advocated notions of the origins of Afrikaans were 'characterized by a deafening silence on or slighting of the non-Germanic or black impact on Afrikaans.' In fact many Afrikaner linguists still limit that influence today to a few lexical items, thereby implicitly dismissing the contribution of black people, for example, to the structure of Afrikaans (1991, 251, 260-1).
} 
continued to exist (1998, 218). Indeed, the distinguished Afrikaner writer, broadcaster, and former newspaper editor Max du Preez noted recently that the language 'has never been richer’ (Roup 2004, 16). Readily apparent in the increasing numbers of singers and writers, for instance, who use Afrikaans as a medium of expression, the 'new vibrancy' of Afrikaans (Vestergaard 2001, 27) is moreover celebrated annually at the Klein Karoo National Arts Festival in Oudtshoorn, which is attended by more than 100,000 fans of Afrikaans theater and music.

South Africa's 2001 census revealed that more blacks than whites spoke the language at home. ${ }^{5}$ This is additional evidence of Afrikaans's linguistic renaissance, of the unfinished, unfolding process of its 'adaptory dialectics of corruption and invention' (Breytenbach 1988, 116), of the 'heartbeat that helped to burst the congested Afrikaner arteries' $(2000,10)$. Of course, this may also be explained in part by the fact that Afrikaans was forced on blacks as a medium of education during the long apartheid years. But as a result of the socio-political changes that have occurred in South Africa since 1994, and of the 'concomitant democratization' of the broad South African speech community (Kotzé 2003, para. 27), the language has also lost its 'tutelage, its dependency, its privileged link with the state' (Dimitriu 1997, 87). Today, it consists of, if not embraces and incorporates, several sub-languages, or alternative forms (Adhikari 1996, 14). This development further dramatizes the 'bleeding-in of images of different origins' and the transformation of the result into something totally different. According to Breytenbach (1986, 102), both phenomena accompany the inherent and ongoing bastardization and metamorphosis of Afrikaans, which fifteen years before the most recent census he had recognized as not 'belonging' to the whites. While Eastern Frontier Afrikaans (Oosgrensafrikaans), which was spoken by privileged whites, became the 'standard,' 'pure' or suiwer Afrikaans during the apartheid years, non-white forms now include Cape Afrikaans (Kaapse Afrikaans) and Orange River Afrikaans

\footnotetext{
${ }^{5}$ Of the 13.3 percent of the South African population speaking Afrikaans, 68 percent live in the Northern Cape, 55.3 percent in the Western Cape, 14.4 percent in Gauteng, 11.9 percent in the Free State, 9.3 percent in the Eastern Cape, 7.5 percent in the North West, 6.2 percent in Mpumalanga, 2.3 percent in Limpopo, and 1.5 percent in KwaZulu-Natal.

Available:http://www.southafrica.info/ess_info/sa_glance/demographics/census-main.htm $>$ [Accessed Nov. 2003].
} 
(Oranjerivierafrikaans), as well as various counter-hegemonic discourses and antilanguages (Mesthrie 1996, viii). The Afrikaans as spoken in the countryside of Gauteng is very different from the Afrikaans one might hear spoken by whites on the campus of the traditionally Afrikaans-speaking University of Pretoria. In the same way, popular, or everyday 'street' Afrikaans is as distinct from the formerly 'official' Afrikaans as is the non-standard gangster and black yuppie patois, tsotsitaal—also known as flytaal or flaaitaal, meaning 'smart talk' or 'jive talk.' This dynamic, rapidly evolving and varying creole of Afrikaans, English and black languages such as Zulu and Sesotho, which is widely spoken by males in urban areas, developed in the mines and places such as Sophiatown, to make communication easier among the different language groups. Similarly, Kaaps_also known as Kapie-taal—or the dialect of Cape Afrikaans spoken in the areas near Cape Town by 80 percent of the Coloured community, and which includes English and Xhosa words, is rising in importance. ${ }^{6}$ Understandably, as increasing numbers of Afrikaans speakers find jobs in the media, and as writers from the formerly marginalized groups of the Afrikaans community gain access to production channels (Wasserman 2000, 96), previously non-standard variants are becoming sanctioned and more widely accepted (Kotzé 2003, para. 27).

This diversity in varieties of Afrikaans spoken as a first language in South Africa today results in part, Breytenbach explains (1999, 35), from 'the glorious bastardization' of the 'men and women mutually shaped by sky and rain and wind and soil' who speak it. Just as Afrikaans was spoken mainly by 'coloured' people before attempts were made to wrestle it away from them and consciously transform it into a 'white man's language' (Brink 1998, 106), the name 'Afrikaner’ designated mainly people of mixed blood in the eighteenth and most of the nineteenth centuries. As André Brink notes in a text on the Afrikaners that was commissioned and published by National Geographic Magazine in the 1980s, when the British threatened the survival of the small Boer republics that had been established in the Transvaal and Orange Free State in the last quarter of the

\footnotetext{
${ }^{6}$ In her essay on shame and identity in the Cape coloured community, Zoë Wicomb points out that when Afrikaans was rejected by blacks as the 'language of the oppressor', in 1976, there was a movement amongst coloureds in the Cape Province to dissociate their first language from oppression. Kaaps asserted 'a discursive space for an oppositional colouredness that aligned itself with the black liberation struggle' (1998, 97).
} 
nineteenth century, a sense of national, racial, and religious consciousness arose among South Africans, mainly of Dutch descent: 'from then onwards “Afrikaner” acquired a more explicit political and religious connotation and Afrikaans was deliberately propagated as a “white” language’ $(1998,76)$. But for most of the twentieth century, the definitive bastardy of the Afrikaners, considered by Breytenbach to be 'one of the most mixed and mixed-up tribes of history' $(1988,115)$, who under the laws of the Dutch East India Company once spoke Dutch and whose members were commonly called baster, or by the Dutch word bastaard (Giliomee 2003, 40), was covered up. As Breytenbach points out, it was downplayed, if not made invisible, by the 'tribe-bound blindness' $(1986,77)$ of the governing Nationalist Party (NP), leaders of the so-called 'white tribe of Africa' (Brink 1998, 77).

By attempting to protect the 'fallacious purity' (Breytenbach 1988, 115) of the Afrikaners, the NP necessarily but problematically 'strain[ed]' its surroundings through a 'simplifying eye' (1986, 60). From 1948 to 1994, when the first free elections were held in South Africa, the NP's totalitarian regime ran the country. It brainwashed generations, 'constantly redefin[ing] purity' $(1986,60)$ under what Breytenbach in 1980 termed 'the law of the bastard' (156) in his characteristically apt but cheeky fashion. The NP got itself 'entangled in a frenzy of frontier tracing, creating weals, cutting into the living fibre of family and nation' $(1996,15)$. As a result of 'separate development' and the 'pass' laws, of 'bureaucratic arbitration, tribal superstitions and ideological genetics' (1988, 125), the government moved people 'willy-nilly to justify demarcations, expropriations' (1993, 91). As a consequence, those who during the years of apartheid so desperately wanted to validate their power and consolidate their 'supposed tribal identity,' offended others; they fenced off, defended, and entrenched themselves. At the same time they retained what they had won. They made their difference and their illegitimacy the norm, if not the ideal. They were indeed 'a bastard people with a bastard language' who had fallen into 'the trap of the bastard who acquires power' $(1980,156)$.

Yet the Afrikaner statesmen were, Breytenbach adds, little more than 'degenerate descendants crossing off lives with a stroke of the pen behind their desks of State' (1993, 
175). They were in reality not the spokespeople of some 'purer' culture but the 'offshoot of a shotgun marriage' $(1986,46)$. They were the offspring of an inevitable intermixing between colonized people and colonizers, of liaisons between Europeans, slaves, Khoi and subordinate blacks. They were, as a result, the descendants of sailors, mercenaries, downgraded civil servants, and 'difficult' minorities such as the Huguenots. Their ancestors were emigrants who were either forced off the northern continent or ill-adapted to it. Just as the syllables of Afrikaans place names have, Breytenbach observes, weathered to a 'smooth sheen from being told through the fingers,' so too their history has been effaced with time and their stories modified for political reasons. ${ }^{7}$ With the 'abscess' that was 'adroitly used by those in power to divert attention from other developments' now lanced, and with the remaining shackles of apartheid lifted, those stories can finally be told. Their resonance can be researched and recognized, and the true beauty in their bastardy beheld:

Riviersonderend, Bredasdorp, Swellendam, Stormsvlei, Halfaampieskraal, Buffeljagsrivier, Leeurivier, Voorhuis, Karringmelk, Soetmelkrivier, Reisiesbaan, Dekriet, Suurbraak. Listen, there’s a story buried behind each and every one of them. Whose? My forebears with the deep eyes of injured baboons and the cumbersome hands and the dark chintz dresses? My other ancestors in their borrowed clothes and the ostrich feathers in their hats? Those who had the memory of rocking ships in their gait? Those who roamed for centuries behind flocks of beasts, from oblivion to an inaccessible skyline? (Breytenbach 1993, 27-8)

Breytenbach's rhetoric intervening within a rich literary context, he celebrates the South African landscape in an attempt to elaborate on his national self-identification (Foley \& Carr, para. 39) through extension. The 'local' stories buried behind these Western Cape toponyms echo and thus include those of all of his bastard brethren, whether those of the seas or sands, slaves or nomads, trekboere or burghers, Huguenots or Hottentots.

The situation, Breytenbach reminds us $(1986,55)$, is essentially no different from that of 'the pale virgin with the dark-skinned brood.' From the outset, he explains $(1986,189)$, Afrikaners suffered from the 'rigid sense of insecurity of the half-breed.' But they passionately affirmed the nature and principles of their tribe:

Locally non-European blood was mixed in; the blood of slaves, the blood of the conquered ones. Neglected, unsupported and unprotected by the motherlands - until diamonds and gold were

\footnotetext{
${ }^{7}$ There is notably increasing tension stemming from the perception among many people in South Africa that cultural identity can only be linked to African names. See, for instance, Kasrils (2000), Brandt (2002) and Machaba (2003).
} 
found - they soon imposed, in the first place upon themselves, their view of what they thought themselves forced to be: a new 'people', still White; an extension of European culture-which meant Calvinist puritanism —into hostile but covetable surroundings [....] Doubt will be suppressed, purity must be preserved, descendence is to be white-washed and there results a pathetic clinging to 'European’ culture $(1986,55)$.

With their blood estimated to be 71 percent 'non-white’ (Brink 1998, 77) and their minds 'warped’ by 'European exclusivism' (Breytenbach 1993, 80), they pretended to be what they were told they ought to be ('what they thought themselves forced to be'), with the 'outward and fossilized signs of European ways.' As these 'unassimilables' (1986, 55) were offloaded onto the Third World, the métissage, or 'new mixture of existing truths' (1993, xiii) began. In the 'mixing' — the suppression of doubt - the bastard origins or non-European colorations were whitewashed.

\section{From Bastardy to the Greater Othering}

After Nelson Mandela was freed from prison and the ban on the African National Congress (ANC) was lifted, Breytenbach traveled from France to South Africa. He had not revisited the country since being released from prison there in 1982. Upon arriving, in addition to English he heard German and Portuguese being spoken outside the airport. What right, he wondered, did these speakers of 'foreign' tongues, these apparent 'intruders', have to strut arrogantly on the tip of the African continent? As they walked their luggage to the parking area, they acted like long-time residents, as though South Africa - with which and from which he found himself schizophrenically identified and dissociated (Reckwitz 1993, 13)_belonged to them. Breytenbach’s self-posed rhetorical questions gave rise to others, equally as uncomfortable, and all pushing definitional and national limits:

But then, since when is this 'my' country? Who am I? I and my kind, those who look and speak like me? And the blacks? Of course the country is theirs, that's what the struggle has been all about and am I not black too? Yes, but actually the land belongs only to those who are locked in a battle for life and death. Can there be degrees of nativeness? Black and Boer and brown, OK. Indian? Come now, do I really see them as fully South African? And the Anglo-whites? Wait a minute there, don't ask all these uncomfortable questions. The other white immigrants then-Greek, Dutch, Polish, Italian, German, Portuguese? How long before they can qualify as African? And the black immigrants from Mozambique and Botswana and even further north? Should they have a better claim than the pale Europeans? $(1993,9)$

One recent tendency in the effort by 'enlightened' Afrikaners such as Breytenbach to negotiate these 'degrees of nativeness' has been to couple an Afrikaans identity with 
other identities. In order to avoid the awkward disqualifications prompted by the identity politics of pitting blacks, Boers, and Coloureds against Indians and whites of British stock, for example, certain Afrikaners now refer to themselves in dual terms, as 'Afrikaners and South African,' 'Afrikaners and Afrikaanses' (Giliomee 2003, 664). The latter appellation was recently invented to designate all Afrikaans speakers, regardless of their race. In the subtitle to his work on the 'tough choices' South Africans face today, Van Zyl Slabbert notably proclaims himself an 'Afrikaner African.' Others refer to themselves as members of 'the Afrikaner community' (Schmidt 2003, para. 7), or in terms of the language they speak at home, as 'Afrikaans-speakers,' 'Afrikaans-users' (Van Zyl Slabbert 2000, 82). ${ }^{8}$

With the recognition there have always been 'alternative' Afrikaners and that it is 'normal' to be 'different' (Breytenbach 2000, 18), the 'blueprint' of the Afrikaner has been broken. ${ }^{9}$ Yet despite the consequent flux of Afrikaner 'identity,' given the opening up of previously sacrosanct Afrikaner ‘enclaves’ to all races (Schalkwyk 1994, 43) and the move to transcend Afrikanerhood into a larger whole (Brink 1998, 123), Breytenbach is hopeful that his bastard people will be able permanently to free themselves of the yokes of the past. He believes that together with their South African compatriots Afrikaners can participate in the 'memory-making' of the 'greater Othering,' 'die Groot Andersmaak' (1996, 31), the remaking of South Africanness by appropriating Khoi tradition through mixing and 'Other-standing' $(1996,148)$. Afrikaners can thereby rearticulate the relationship between subjects and discursive practices, by establishing some form of supra-ethnic or supra- ‘national' South African nationality or citizenship (1986, 180). They can knit the 'torn fibres' of apartheid finally into 'a serviceable national cloth' (1996, 44). Breytenbach sees this self-reinvention as perpetual and ongoing. It is both an itinerary and topography of 'becoming in the making' (1996, 31). Likewise, it is an

\footnotetext{
${ }^{8}$ For Adriana Stuijt, Afrikaners are really—and only—Boers. They have lost their ethnic identity largely due to the efforts during the apartheid years of the Afrikaner Broederbond, which deliberately wrote their true history from the history books. She cautions that they are at risk today of losing their ethnic identity even further and of losing their rights to remain in the 'unique, ethnically different nation' of South Africa (2004, para. 8).

${ }^{9}$ For more on the role of such 'alternative' Afrikaners in the South African press during apartheid see for instance Claassen (2000).
} 
'exciting challenge' and a 'miserable fate.' Afrikaners must, in other words, keep on reinventing their identity, authenticity, and usefulness. They must decide upon the weight to ascribe to historical memory. They must determine and maintain the appropriate, sustainable balance for keeping alive the creative tension between sharedness and differences $(1996,9)$.

As a means to supersede the 'maniacal cutting and chopping' of identities $(1986,94)$ that for so long has been prevalent in South African society, and thereby to move from the early African past to a new African future, Breytenbach reaches back into that past to bring things full-circle. Suspicious of the centralizing and homogenizing tendencies of the current ANC government, he understands that because South Africa consists of strong and diverse groups, is a 'construct,' the 'result of dreams,' and a 'dangerous puzzle' (2000, 17), it challenges and tests traditional notions of a nation-state. The definitions of cultural identity that have long had currency elsewhere are ill-fitting and outdated there today (Dimitriu 1997, 86). He recognizes that definitions are 'perforce part-time and shifting' $(1996,15)$. In the place of these clumsy efforts to give new ideological content to the label of 'Afrikaner,' Breytenbach favors replacing it altogether.

He thus revives and poetically revalues the ancient term Afriqua, which was the name given centuries ago to the mixed offspring of the Khoi and passing sailors (1993, 227). With the suffix -qua added to Khoi names indicating 'the people, the sons, the men of' (1993, 227), this resurrected term conveys the 'true mongrel nature' of Afrikaner culture (Jacobs 2000, 78). It better fits their cultural complexity than an invented, if not stilted, term such as 'Afrikaanses.' Furthermore, to ally Afrikaners and Khoi in such a way acknowledges the 'unwritten' history, customs, and attitudes of the Khoi, the 'invisible presence' of the Khoi in the make-up of Afrikaners (Breytenbach 1993, 211). ${ }^{10}$ For three centuries, Breytenbach asserts (1996, 100), his 'people,' a 'profound métissage of cultures,' have been 'nothing other' than Afriquas, or 'of Africa' (1993, 75). The

\footnotetext{
${ }^{10}$ An anonymous reviewer of this essay suggests that such an allying of Afrikaner and Khoi might be viewed more cynically as a pitting of local ('Cape') against national politics, an attempt to offset the confident majority of 'Africans' and the ANC. See Breytenbach's 'open letters' to Nelson Mandela (1991 and 1994) for more on his fraught relationship with the ANC.
} 
potential value of the Afriqua culture, as he sees it, will lie in the extent to which it allows other cultures to coexist $(1986,48)$. The ‘bastardization’ at its heart, its engine, can thereby not only give rise to linguistic variation, it should also be looked at closely as a motivation for an ongoing intellectual, cultural, and political renaissance that charts new terrain for democracy, and pushes boundaries or a 'theological, political, ideological, and practical enquiry into the methods and contents of Africanization.' Afrikaners as Afriquas might, as a result, attempt to see where they fit into the Third World, outline their role in the south-north relationship, and determine the nature and trace the results of their reconciliation in this new, more inclusive and revealing cultural context (1996, 35).

For Stuart Hall, cultural identity can be seen in two ways: as fixed or dynamic. In the first way, it is viewed in terms of one shared culture, much like the Afrikaner 'culture brokers' viewed their own Afrikanerskap during the years of apartheid: 'a sort of collective "one true self", hiding inside the many other, more superficial or artificially imposed "selves" which people with a shared history and ancestry hold in common' (1994, 393).

Breytenbach's view that it is no longer necessary to affirm one's separateness in order to fix one's identity (1993, 74-5) conforms to the second 'unsettling,' less familiar view of cultural identity described by Hall. The supra-ethnic, supra-'national' Afriquan cultural identity that Breytenbach envisions is a fragmented, discontinuous, and dynamic process. It is not the static, stable framework of meaning to which the architects of apartheid had clung in their efforts to fix the state of being that they had claimed for Afrikanerskap. The cultural identity of the Afriquas is as much a process of 'becoming' as a state of 'being.' It is a positioning towards history and the future, within full knowledge that the schism with the apartheid past is complete yet always already subject to the continuous 'play' of history, culture, and power (Hall 1994, 394).

Reconciliation for Breytenbach is also a 'hybridization' (1996, 35). But while Breytenbach might believe the term to invoke the loss of domination and the acceptance of change, hybridity is also a contested notion. Robert Young, for example, cautions that hybridity was historically used to refer to the successful breeding across species (animals, plants) that resulted in sterile offspring. Thus the transfer of the concept 'hybrid' to races 
of people implicitly equates differences of race to those of species and dooms the offspring of interracial couplings to sterility. Accordingly, Young claims, 'the interval that we assert between ourselves and the past may be much less than we assume. We may be more bound up with its categories than we like to think’ $(1995,28)$.

Corresponding to the 'internal resistance' that a 'complicit postcolonial' offers (Wasserman 2000, 99), could the concept of hybridity articulated, indeed glorified by Homi Bhabha more aptly contextualize the challenges and promises inherent in negotiating, embracing the inclusive, recuperative Afriquan cultural identity championed by Breytenbach? As Bhabha shows in his study on the location of culture (1993), the most creative forms of cultural identity work counter-hegemonically. They are produced in the boundaries between forms of difference, in the intersections and overlaps across the spheres of class, gender, race, nation, generation, and location. They thereby promise to undermine and stifle the cultural differences that, in the context of this discussion, were oversimplified during the apartheid years and forced into binaries of 'race,' into the notion of 'homelands,' and the old South Africa's devastating dialectic of 'difference.' Always relational and shifting, with its meaning and symbols ultimately having no primordial order or fixity, could Afriquan culture be constructed in Bhabha's contradictory and ambivalent 'Third Space' of enunciation? Can the past, racist and exclusive signs of Afrikanerdom be reappropriated, translated, rehistoricized, and read anew in this space, where claims based on a hierarchical purity of cultures might no longer be tenable? $(1994,37)$.

Yet, when tested in the South African context, Bhabha's theory of hybridity is problematic. Given the country’s many years of suppressed miscegenation and slave origins (Easton 2002, 243), and its codification of 'hybridity' in the exploitable adaptability of a 'coloured' identity (Noyes 2000, 52), the concept of the hybrid can also be seen as offensive. Because of the specificity of the Cape Coloured community, for example, the concept would at least require further contextual elaboration. As Zoë Wicomb argues, the 'shameful' vote by many Cape colored people for the NP in South Africa's first democratic elections represents the 'failure, in coloured terms, of the grand 
narrative of liberation.' Working-class coloured communities were led by the NP to believe that Africanization could only be achieved at their expense and would ultimately deprive them of their culture $(1998,99)$. As a result, their celebration of 'inbetweenness' served conservatism. Rejecting Bhabha's theory, Wicomb asks how it might be possible to frame more sensibly the questions of postcolonial 'hybridity' and identity. How might we better understand 'the territorialization or geography of belonging within which identity is produced'? At what point is 'lived experience' ultimately displaced by 'an aesthetics of theory’? $(1998,94)$.

Wicomb rejects the notion of hybridity as articulated by Bhabha because it cannot account for the current coloured politics in South Africa. Still, Robert Young notes that 'There is no single, or correct, concept of hybridity' $(1995,27)$. The longer history of the term reveals it to be 'perfectly accommodating' (Easton 2002, 243), hence the range of shifting definitions for hybridity. In place of such a contested notion, Wicomb proposes 'multiple belongings' as an alternative way of viewing cultural life in the larger South African community. Perhaps this is more in line with the inclusive, recuperative, 'creolized’ (Nuttall \& Michael 2000, 7) Afriquan culture envisioned by Breytenbach.

Like the term 'Afriqua,' or even 'identity,' which is 'a temporary awareness meeting and mating moment to moment’ (Breytenbach 1996, 159), Breytenbach’s poem, '7.8,' might as a consequence take on new meaning and be revalorized today. The poem was anthologized in And Death White as Words (1978), translated into English by Ernst van Heerden, and published during the apartheid years. Its title suggests temporariness in movement or incremental progress. In rewriting the 'Lord's Prayer' to be more accommodating, Breytenbach's poem seems actually to rehearse the sense of multiple belongings and inclusiveness by which the notion of hybridity might also be revealed as reconciliatory:

Our generous God of all that is sweet and beautiful

Let thy name always stay stored in us and therefore hallowed,

Let the republic now come about,

Let others shoot their will away-

Let go! Let go!

So that we too may have a say,

A say like a sea 


\begin{abstract}
Around the coasts of our heavenly Still Mountains
Give us this day the chance to earn our daily bread and the butter, the jam, the wine, the silence, The silence of wine,

And lead us into temptation of various kinds

So that love may jump from body to body

Like the flames of being-being from mountain to mountain

Brambles of fire brought to the whitest moon

But let us deliver ourselves from evil

So that we may reckon with the trespass of centuries

Of stored up exploitation, of plunder, of swindling,

And the last rich man dies, poisoned by his money

For ours is the kingdom, the power and the glory,

For ever and ever and just as ever

As the shadows and the frontier posts of man

When he tears the earth from heaven like a god
\end{abstract}

Ah men! Ah men! Ah men! $(1978,65)$

Traditionally suggesting ownership that is at the same time supreme (the prayer of the Lord) and collective (the prayer to the Lord, the shared father), God's will in Breytenbach's revised version of this well-known prayer gives way to the new Afriquan nation to be characterized by 'love,' by 'temptation of various kinds' (even if myriad bastard births might result), and by the belief in the shared value, the capacities of all ('Ah men!'). ${ }^{11}$ This can only come about, however, by giving up supreme, selfish ownership ('Let go!') and by replacing the individual will ('Thy will be done,' 'Let others shoot their will away') with the collective will ('Let the republic now come about'). Echoing a verse from the United States' national anthem ('Oh, say can you see'), Breytenbach asks that the voice of all Afriquans ('A say like a sea') be finally heard. Belonging to all, rescued from centuries of 'trespass' and 'exploitation,' this land that he prays be 'torn from heaven' might thus resemble heaven on earth. With 'death-white' a phantom shade from South African's past thus replaced with the all-inclusive colors of the Afriquan rainbow, with 'thine' ceding to 'ours,' the divine made part of all menevidence of the refinement of knowledge and insight that is a sine qua non for survival (Breytenbach 2000, 18) —, the true beauty and enunciative power of Breytenbach's

\footnotetext{
11 The poem is originally from Breytenbach’s 1970 volume of love poems, Lotus.
} 
hopeful, 're-articulated,' admittedly 'bastardized' prayer remains to be seen in the twenty-first century and beyond.

\section{Reference List}

Adhikari, M. 1996, 'Coloured identity and the politics of language: The sociopolitical context of Piet Uithalder's 'Straatpraatjes' column', in Straatpraatjes: Language, Politics and Popular Culture in Cape Town, 1909-1922, eds R.H. Pheiffer, F. Ponelis and Hein Willemse, J.L. van Schaik, Pretoria, 1-17.

Alexander, N. 2003, review of The Afrikaners: Biography of a People, Tafelberg, Cape Town, Back cover.

Baines, G. 1998, 'The Rainbow Nation? Identity and Nation Building in Post-Apartheid South Africa,' Mots pluriels 7.

Available: $<$ http://www.arts.uwa.edu/au/MotsPluriels/MP798gb.html [Accessed Dec. 2003].

de Beer, E. 2003, 'It's Wrong to Say Afrikaners cannot stand together'. Available: http://allafrica.com/stories/200310020049.html [Accessed Oct. 2003].

Bhabha, H. 1994, The Location of Culture, Routledge, New York.

Brandt, G. 2002, 'Burton Joseph and his amazing monochrome dreamcoat: on place name change,' Out-Star. Available: http://www.praag.co.za/out-star.htm [Accessed May 2005].

Breytenbach, B. 1978, '7.8.', in And Death White as Words: an Anthology of the Poetry of Breyten Breytenbach, ed. A.J. Coetzee, trans. E. van Heerden, Rex Collings, London, 64-5. 1980, A Season in Paradise, trans. R. Vaughan, Harcourt Brace, New York. 1983a, 'I am not an Afrikaner any more', Index on Censorship 3: 3-6. 1983b, The True Confessions of an Albino Terrorist, Harcourt Brace, New York. 1986, End Papers: Essays, Letters, Articles of Faith, Workbook Notes, Farrar, Straus and Giroux, New York: 1988, Judas Eye, Faber and Faber, London. 1991, 'Panel Discussion following “Cold Turkey”', in The Writer in Politics, eds. W.H. Gass and L. Cuoco, Southern Illinois University Press, Carbondale, 175-91. 1993, Return to Paradise, Harcourt Brace, New York. 1996a, The Memory of Birds in Times of Revolution: Essays on Africa. New York: Harcourt Brace. 1996b, 'An Open Letter to Nelson Mandela, 1991', in The Memory of Birds in Times of Revolution, Harcourt Brace, New York, 74-81. 1996c, 'An Open Letter to Nelson Mandela, 1994', in The Memory of Birds in Times of Revolution, Harcourt Brace, New York, 82-7. 1999, Dog Heart: a Memoir, Harcourt Brace, New York. 2000, 'Fire in the Fingers:a Foreward.', in Tough Choices: Reflections of an Afrikaner African, by Van Zyl Slabbert, Tafelberg, Cape Town, 9-18.

Brink, A. 1998, Reinventing a Continent: Writing and Politics in South Africa, Zooland Books, Cambridge. 
Claassen, G. 2000, 'Breaking the Mold of Political Subservience: Vrye Weekblad and the Afrikaans Alternative Press', in South Africa's Resistance Press: Alternative Voices in the Last Generation Under Apartheid, eds L. Switzer and M. Adhikari, University Center for International Studies, Athens Ohio, 404-57.

Coetzee, J. 1992, Doubling the Point: Essays and Interviews, ed. D. Attwell, Harvard University Press, Cambridge.

Dimitriu, I. 1997, 'Approaches to Translation: Interview with Breyten Breytenbach', Current Writing, 9.1, 68-96.

Dixon, R. 2004, 'Pessimism Hides South Africa’s Gains’, Los Angeles Times, 1 Jan., A4.

Easton, K. 2002, 'Travelling through History, "New” South African Icons: the Narratives of Saartje Baartman and Krotoä-Eva in Zoë Wicomb’s “David’s Story”, Kunapipi, 24.1-2, 237-50.

Foley, M. and M. Carr, 'Signs of Contradiction: Nationalism and the Search for a Democratic “WE”, in National Identity as an Issue of Knowledge and Morality, eds N. Chavchavadze, G. Nodia \& P. Peachey, Georgian Philosophical Studies 1. Available at: http://www.crvp.org/book/Series04/IVA-7/chapter_v.htm [Accessed May 2005].

Giliomee, H. 2003, The Afrikaners: Biography of a People, Tafelberg, Cape Town.

Hall, S. 1994, 'Cultural Identity and Diaspora', in Colonial Discourse and Post-Colonial Theory: A Reader. Eds. P. Williams and L. Chrisman, Columbia University Press, New York, 392-403.

Jacobs, J. 2000, ‘Afrikaners, Africans and Afriquas: Métissage in Breyten Breytenbach’s Return to Paradise, in Postcolonizing the Commonwealth, ed. R. Smith, Wilfrid Laurier University Press, Waterloo, 75-85.

Kasrils, R. 2000, 'Address by the Minister of Water Affairs and Forestry, Ronnie Kasrils, MP, at the Renaming of the Chelmsford Dam to Ntshingwayo Dam,' issued by the Minister of Water of Affairs and Forestry, 6 August 2000. Available at http://www.info.gov.za/speeches/2000/0008081010a1003.htm [Accessed May 2005].

Kotzé, E., 'Effects of Attitudinal Changes Towards Creolization in Afrikaans'. Available: http://www.unb.br/il/liv/crioul/textos/ernst.htm [Accessed Nov. 2003].

Linfield, S. 2000-1, ‘An Interview with Breyten Breytenbach’, Salmagundi, 128-9, 24974.

Louw-Potgieter, J. 1988, Afrikaner Dissidents: a Social Psychological Study of Identity and Dissent, Multilingual Matters, Philadelphia

Machaba, M. 2003, ‘Benny Alexander did it... why can’t I?’, Focus 14.1. Available at: http://www.ukzn.ac.za/focus/pdf/vol14no1/FOCUS\%20PG40-42.pdf [Accessed May 2005].

Mesthrie, R. 1996, 'Foreward', in Straatpraatjes: Language, Politics and Popular Culture in Cape Town, 1909-1922, eds R.H. Pheiffer, F. Ponelis and H. Willemse, J.L. van Schaik, Pretoria, viii-xii.

Moodie, T. 1975, The Rise of Afrikanerdom: Power, Apartheid, and the Afrikaner Civil Religion. University of California Press, Berkely.

Noyes, J. 2000, ‘The Place of the Human', in Senses of Culture: South African Cultural Studies. Eds. S. Nuttall and C. Michael. Oxford: Oxford UP. 49-60. 
Nuttall, S. \& Michael, C. 2000, 'Introduction: Imagining the Present,' in Senses of Culture: South African Cultural Studies, eds S. Nuttall and C. Michael, Oxford University Press, Oxford, 1-23.

'Policy of the Freedom Front'. Available:http://www.vryheidsfront.co.za/index.asp?1=e [Accessed Nov. 2003].

Reckwitz, E. 1993, 'I Am Not Myself Anymore: Problems of Identity in Writing by White South Africans', English in Africa, 20.1: 1-23.

Roup, J. 2004, 'Lost for Words,' Financial Times Weekend Magazine, 8 May, 16.

Schalkwyk, D. 1994, 'Confession and Solidarity in the Prison Writing of Breyten Breytenbach and Jeremy Cronin', Research in African Literatures,25.1, 23-45.

Schmidt, M. 2003, 'The Rediscovery of Afrikaans,' Sunday Times. Available: http://www.suntimes.co.za/2003/10/26/insight/in01.asp [Accessed Oct. 2003].

Steinwand, J. 2002, 'Getting into the Mix without Getting Mixed Up: Decolonizing "Hybridity” in the Novels of Zoë Wicomb and Kiana Davenport', Proceedings of the Annual Red River Conference on World Literature 4. Available: http://www.ndsu.edu/RRCWL/V4/steinwand.html [Accessed Mar. 2005].

Stuijt, A. 2004, 'Boer, Afrikaner or White... Re-Read This and Weep', Reality Digest 1.2 realiteit@boer.co.za, listserv posting, 17 Aug.

Swarns, R. 1999, 'The World: Who is African?; In Apartheid's Wake, A Word Still Divides,' New York Times, 3 Oct., D1.

Van Zyl Slabbert, F. 2000, Tough Choices: Reflections of an Afrikaner African, Tafelberg, Cape Town.

Vestergaard, M. 2001, 'Who’s Got the Map? the Negotiation of Afrikaner Identities in Post-Apartheid South Africa,' Daedalus 130.1, 19-44.

Vryheidsfront Plus/Freedom Front Plus. Available $<$ http://www.vryheidsfront.co.za/index.asp?1=e > [Accessed Nov. 2003].

Wasserman, H. 2001, 'Intercultural Dialogue in Recent Afrikaans Literary Texts: A Discourse of Identity’, in Pretexts: Literary and Cultural Studies 10.1: 37-50. 2000, 'Re-Imagining Identity: Essentialism and Hybridity in Post-Apartheid Afrikaans Short Fiction’, Current Writing, 12.2, 96-112.

Wicomb, Z. 1996, 'Postcoloniality and Postmodernity: the Case of the Coloured in South Africa', AUETSA, Southern African Studies, 1, 5-16. 1998, 'Shame and Identity: the case of the coloured in South Africa.' in Writing South Africa: Literature, apartheid, and democracy, 1970-1995, eds D Attridge and R. Jolly, Cambridge University Press, New York, 91-107. 2002, 'Zoë Wicomb in Conversation with Hein Willemse', Research in African Literatures, 33.1, 144-52.

Willemse, H. 1991, 'Securing the Myth: the Representation of the Origins of Afrikaans in Language Textbooks', in Knowledge and Power in South Africa: Critical Perspectives Across the Discipline, ed. J.D. Jansen, Skotaville Publishers, Johannesburg, 249-63.

Young, R. 1995, Colonial Desire: Hybridity in Theory, Culture, and Race, Routledge, New York. 